\title{
A Game-based Nutrition Education: Teaching Healthy Eating to Primary School Students
}

\author{
(1) Hatice Uzşen, (1) Zümrüt Didar Başbakkal
}

Ege University Faculty of Medicine, Department of Pediatric Nursing, İzmir, Turkey

\begin{abstract}
Aim: The purpose of this study is to determine eating habits of school age children and to evaluate the effect of nutrition education via games on promoting healthy eating habits.

Materials and Methods: The study, which is quasi-experimental with a pre-test/post-test experimental model without a control group, was conducted at a primary school. The population of the study includes 8 -year-old $2^{\text {nd }}$-grade students. The population consists of 59 primary school students who participated in all nutrition education and completed one pre-test and two post-tests. The data were analyzed via descriptive statistics, Wilcoxon-Mann-Whitney-test, McNemar's test, Shapiro-Wilk tests.

Results: According to the findings, 59.3\% of the students didn't have any nutrition education and $84.7 \%$ of them considered their eating habits as good. It was also found that $50.8 \%$ of the students before the training, $30.5 \%$ of them right after the training and $40.7 \%$ of them 3 months after the training stated they skipped one of their meals and that lunch which was the most frequently skipped meal. Although there was no change in consumption of fresh fruit and fruit juice, there was an increase in the consumption of fresh vegetable and vegetable meals, but this was not transformed into behavior. The consumption of dairy products increased and transformed into behavior. The average nutrition knowledge of the students increased both right after the training and 3 months later.
\end{abstract}

Conclusion: It is thought that the nutrition education given to the school age children had a positive effect on their nutrition knowledge, attitudes, behaviors.

Keywords: Eating habits, nutrition education, school age children, game

\section{Introduction}

Schools are an important source for giving nutrition education $(1,2)$. Providing nutrition education by traditional methods only provides information, but actively participating in nutrition education is an interesting and effective method of teaching healthy nutrition behavior (3). With the help of game-based nutrition education instead of straight narration methods and recommendations, students can acquire healthy nutrition behavior $(4,5)$. In nutrition education, the educator and the developer effect of the game are utilized.

Today, increasingly, gaming activities are becoming an integral part of educational programs, and educational and learning activities become effective, permanent, meaningful and enjoyable structures (6). Playing a game and education are complementary methods for healthy eating habits and active lifestyles because the game is motivational, enjoyable, recognizable, irregular, secure and active in the learning process. Making choices, making their own decisions, taking 
responsibilities and entertainment are the components of learning via playing games $(3,7,8)$.

Children, communities, school-based individuals, teachers and health personnel must be conscious and educated about nutrition in order for the school child to be fed an adequate, balanced and healthily diet (9). For this reason, educators, sociologists, economists and planners, physicians and school health nurses should work in a multidisciplinary team approach (1).

The most important person who will implement health education to raise and protect the health of the school-aged child is the nurse (10). Nurses are a key point in determining the nutritional behavior of children and the factors that affect them, determining the children who have inadequate and unbalanced feeding, teaching healthy eating habits to children and getting support in this field by working with other institutions and organizations in the society (11).

In this study, it is thought that the determination of eating habits of the school children and the evaluation of nutrition education via playing are important in terms of raising the health of the school-aged child. The aim of this research is to increase the knowledge of students by giving nutrition education via playing a game and to transform the education information into behavior.

\section{Materials and Methods}

\section{Research Design}

The study was carried out with semi-experimental, pretest and post-test trial models without a control.

\section{Sample}

One hundred twenty 8 -year-old $2^{\text {nd }}$ grade students going to Murat Reis Primary School between MarchJune 2014 were invited to participate in the study and they received the nutrition education. Children with chronic illnesses that affect food allergy or food intake and children with any medical nutrition restriction were not included in the study. In the collection of the data, a survey, prepared by the researcher in accordance with the literature, containing the descriptive characteristics, nutritional habits and nutrition information of the school children was used. Expert opinions were received from four academician nurses for the information form and pre-test, post-test forms.

The research was planned to be done with 120 second grade students, the research data were collected before, immediately after and three months after the nutrition education, but the evaluations were based on the 59 students who participated in all three of the questionnaires.

\section{Intervention}

After the preliminary study was completed and the permits were received, the study was carried out for a total of 2 weeks as one lesson per week ( 45 minutes). The surveys of the study which were done as pre-test and post-test were repeated after three months and the efficiency of nutrition education via playing a game was examined.

In the first week of the education via the game, the course was given as a slide show and general nutrition information was given and then this information was reinforced with a card game. Healthy morning breakfast, lunch and dinner menus were prepared together with the students using food cards.

In the second week of nutrition education, baskets of food groups were prepared and taken to the school. By mixing food groups, it was required that students put the correct food in the correct basket. In addition, a food group game was played to find food not belonging to the basket. Then, the students were selected for a role play; the scenario was explained and the roles were distributed. The role play was improvised. One of the scenarios was portraying the mother and the child who go to the market and shop for healthy food, and the other one was discussions about healthy and adequate nutrition of family members eating dinner. After the role play, the game was discussed. Each class had a "Healthy Nutrition Post", and students were given the opportunity to examine it, and the main points of healthy eating were consolidated with posters.

After the education was completed, nutrition education was conducted with the voluntary participation of the school administration, class teachers and parents. The education was conducted in the form of questions and answers.

The canteen and environmental conditions were evaluated in terms of hygiene, food cleaning, preparation, and food variety.

\section{Instruments}

Two data collection tools were used in the study, namely the "Questionnaire for the Nutrition Habits of the School Age Child" which includes eighteen questions and the "Questionnaire for the Nutrition Knowledge of the School Age Child" which includes twenty questions. The questionnaires were developed by researchers and expert opinions were obtained.

\section{Ethical Explanations}

The required permission was obtained from the Scientific Ethics Committee of Ege University Nursing Faculty, the Ministry of Education and the Primary School attached to the Ministry of National Education (approval 
number: 27344949-1267). Verbal and written approvals were obtained from parents and children prior to the children's education, by explaining the purpose of the study, benefits to be obtained from the study and time to be spent for the education.

\section{Statistical Analysis}

In data analysis with SPSS 16.0 statistical program, numbers and percentages, Wilcoxon-Mann-Whitney test and McNemar's test were used for the evaluation of information on the children and their nutrition habits before and after the intervention, Shapiro-Wilk test was used for the evaluation of nutrition information before and after the intervention.

\section{Results}

According to the obtained data, $54.2 \%$ of the students participating in the study were female, and $45.8 \%$ of them were male. The average weight of the females was $27 \mathrm{~kg} \pm 4$, and average height was $130 \pm 4 \mathrm{~cm}$. The average weight of the males was $29 \mathrm{~kg} \pm 5$ average height was $130 \pm 6$ $\mathrm{cm} .16 .9 \%$ of the students were thin, $54.2 \%$ were normal, $28.8 \%$ were overweight. It was determined that $84.7 \%$ of the students identified their pre-education own eating habits as "good". This rate increased to $93.2 \%$ after the education.

It was determined that $78 \%$ of the students stated that they consumed at least three meals a day before the education. This ratio was $64.4 \%$ after education and $61 \%$ three months after the education. Although there seems to be a decrease in the frequency of food consumption, the frequency of food consumption of three meals and above increased.

According to the obtained data, $50.8 \%$ of the students stated that they had skipped meals during the day before the education. This ratio was 30.5\% after the education and $40.7 \%$ three months after the education. There is a significant difference between pre-education and posteducation mean skipping behaviors of the students $(p=0.004)$.

There was no significant change between those who consumed fruit and freshly squeezed juice before (55.9\%) and after training (54.2\%) and three months after the education $(55.9 \%)$, and the individuals who consumed vegetables and vegetable foods did not translate into behavior despite the increase after the education from $49.2 \%$ to $54.2 \%$. Students were consuming milk and dairy products predominated before the education (78\%), after the education (79.7\%) and three months after the education (86.4\%) (Figure 1). The egg consumption rate showed an increase after education from $57.6 \%$ to 62.7 but decreased three months after the education (50.8\%).
There was no significant change in the consumption of red meat and poultry which was at a level of 2-4 times a week. Seafood consumption increased after the education (27.1\%) and decreased three months after the education (20.3\%) (Table I). Dry legume consumption increased after the education ( $35.6 \%$ ) and three months after the education (39\%) (Figure 2).

The percentage of those who did not consume sugar and sweetened foods did not change after the education $(18.6 \%)$, and decreased three months after the education (10.2\%). The percentage of those who did not consume energy drinks increased significantly three months after the education (79.7\%).

There was no significant difference between preeducation, post-education, and 3 months' post-education in the general sense among the food consumption frequency of the students $(p<0.05)$.

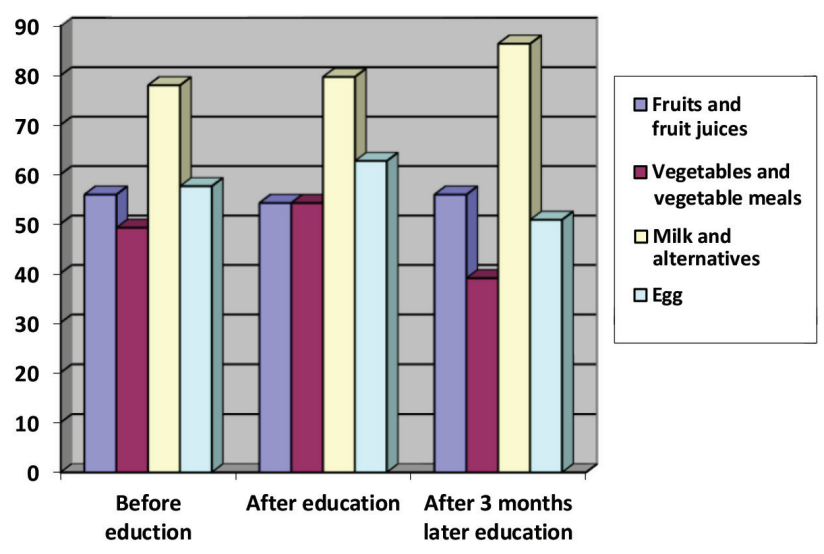

Figure 1. Consumption graphic of foods being consumed daily by school-age children

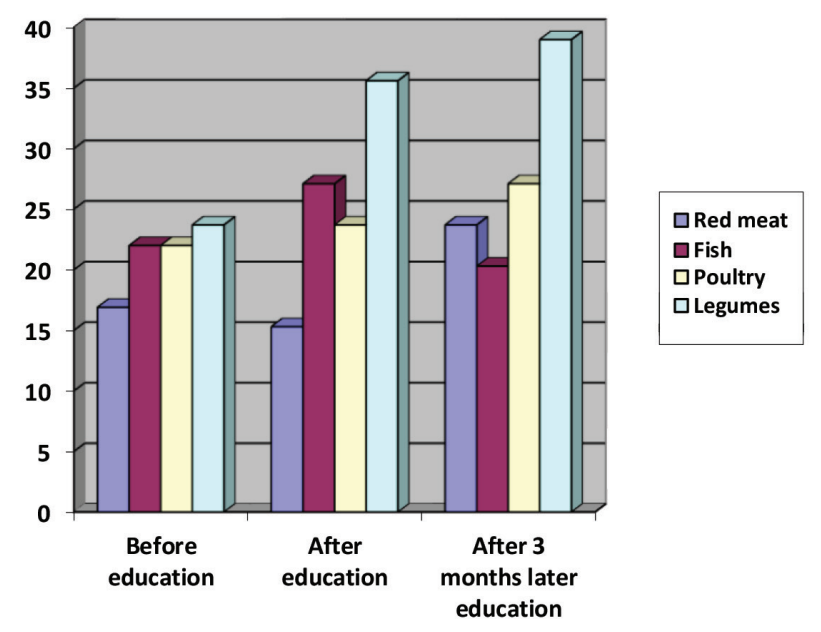

Figure 2. Consumption graphic of foods being consumed 2-4 times a week by school-age children 
Before the education, 30.5\% of the students had been doing something while eating. This rate did not change after the education (28.8\%) but increased three months after the education (47.5\%). This ratio did not show a significant change after the education and three months after the education.

According to the obtained data, $44.1 \%$ of the students take a lunch box to school. $54.2 \%$ of those who take a lunch box do not consume the food inside it. It was determined that $50.8 \%$ said they did not consume these foods because they did not like them. After the education and three months after the education, there was no change in the ratio of students who took a lunch box to school. The percentage of students who buy food from the canteen was $61 \%$, this percentage dropped to $44.1 \%$ after the education but did not transform into behavior three months after the education. Fatty foods such as toast, sandwich and hamburger were the most commonly consumed ones from the canteen (37.3\%), but this ratio decreased after the education (27.1\%), but it did not change three months after the education.

Before the education, $86.4 \%$ of the students took part in daily physical activity. There was no significant change in physical activity after the education and three months after the education.

The average score of pre-education nutrition information for students is 79, 81 after education, 89 three months after the education. Nutrition information of $62.7 \%$ of the students was "very good" before the education, nutrition information of $71.2 \%$ after education and $91.5 \%$ three months after the education was "very good" (Table II).

Table I. School-age children's frequency of food consumption

\begin{tabular}{|c|c|c|c|c|c|c|c|c|c|c|c|c|c|c|c|c|c|c|c|c|}
\hline \multirow{3}{*}{ Food } & \multicolumn{10}{|c|}{ Before education } & \multicolumn{10}{|c|}{ After education } \\
\hline & \multicolumn{2}{|c|}{ None } & \multicolumn{2}{|c|}{$\begin{array}{l}\text { Once a } \\
\text { month }\end{array}$} & \multicolumn{2}{|c|}{$\begin{array}{l}\text { Once a } \\
\text { week }\end{array}$} & \multicolumn{2}{|c|}{$\begin{array}{l}\text { Two-four } \\
\text { times a } \\
\text { week }\end{array}$} & \multicolumn{2}{|c|}{$\begin{array}{l}\text { Every } \\
\text { day }\end{array}$} & \multicolumn{2}{|c|}{ None } & \multicolumn{2}{|c|}{$\begin{array}{l}\text { Once a } \\
\text { month }\end{array}$} & \multicolumn{2}{|c|}{$\begin{array}{l}\text { Once a } \\
\text { week }\end{array}$} & \multicolumn{2}{|c|}{$\begin{array}{l}\text { Two-four } \\
\text { times a } \\
\text { week }\end{array}$} & \multicolumn{2}{|c|}{$\begin{array}{l}\text { Every } \\
\text { day }\end{array}$} \\
\hline & $\mathbf{n}$ & $\%$ & $n$ & $\%$ & $\mathbf{n}$ & $\%$ & $\mathrm{n}$ & $\%$ & $n$ & $\%$ & $n$ & $\%$ & $\mathrm{n}$ & $\%$ & $\mathbf{n}$ & $\%$ & $\mathbf{n}$ & $\%$ & $n$ & $\%$ \\
\hline Meat & 25 & 42.4 & 11 & 18.6 & 13 & 10.2 & 9 & 16.9 & 9 & 11.9 & 13 & 22.0 & 15 & 25.4 & 13 & 22.0 & 9 & 15.3 & 9 & 15.3 \\
\hline Fish & 8 & 13.6 & 14 & 23.7 & 15 & 25.4 & 13 & 22.0 & 9 & 15.3 & 4 & 6.8 & 15 & 25.4 & 12 & 20.3 & 16 & 27.1 & 12 & 20.3 \\
\hline Poultry & 8 & 13.6 & 12 & 20.3 & 15 & 25.4 & 13 & 22.0 & 11 & 18.6 & 7 & 11.9 & 14 & 23.7 & 14 & 23.7 & 14 & 23.7 & 10 & 16.9 \\
\hline
\end{tabular}

$p<0.05$

Table I. Continued

\begin{tabular}{|c|c|c|c|c|c|c|c|c|c|c|c|c|c|c|c|}
\hline \multirow{3}{*}{ Food } & \multicolumn{10}{|c|}{ Three months after education } & \multicolumn{3}{|c|}{$\begin{array}{c}\text { Wilcoxon t-test } \\
\text { Asymp. Sig. (2-tailed }\end{array}$} & & \\
\hline & \multicolumn{2}{|c|}{ None } & \multicolumn{2}{|c|}{$\begin{array}{l}\text { Once a } \\
\text { month }\end{array}$} & \multicolumn{2}{|c|}{$\begin{array}{l}\text { Once a } \\
\text { week }\end{array}$} & \multicolumn{2}{|c|}{$\begin{array}{l}\text { Two-four } \\
\text { times a } \\
\text { week }\end{array}$} & \multicolumn{2}{|c|}{$\begin{array}{l}\text { Every } \\
\text { day }\end{array}$} & \multirow[t]{2}{*}{$\begin{array}{l}\text { Before } \\
\text { education } \\
\text { - after } \\
\text { education }\end{array}$} & \multirow[t]{2}{*}{$\begin{array}{l}\text { Before } \\
\text { education- } \\
\text { after three } \\
\text { months }\end{array}$} & \multirow[t]{2}{*}{$\begin{array}{l}\text { After } \\
\text { education- } \\
\text { after three } \\
\text { months }\end{array}$} & \multicolumn{2}{|c|}{ Total } \\
\hline & $\mathbf{n}$ & $\%$ & $\mathbf{n}$ & $\%$ & $\mathbf{n}$ & $\%$ & $\mathbf{n}$ & $\%$ & $\mathbf{n}$ & $\%$ & & & & $\mathbf{n}$ & $\%$ \\
\hline Meat & 19 & 32.2 & 8 & 13.6 & 13 & 22 & 14 & 23.7 & 5 & 8.5 & 0.055 & 0.252 & 0.613 & 59 & 100.0 \\
\hline Fish & 1 & 1.7 & 17 & 28.8 & 28 & 47.5 & 12 & 20.3 & 1 & 1.7 & 0.113 & 0.507 & 0.026 & 59 & 100.0 \\
\hline Poultry & 5 & 8.5 & 15 & 25.4 & 17 & 28.8 & 16 & 27.1 & 6 & 10.2 & 0.829 & 0.717 & 0.793 & 59 & 100.0 \\
\hline
\end{tabular}

$p<0.05$

Table II. Nutritional information scores for school-age children

\begin{tabular}{|l|l|l|l|l|}
\hline $\begin{array}{l}\text { Questionnaire for the Nutrition Knowledge of } \\
\text { the School Age Child }\end{array}$ & $\begin{array}{l}\mathbf{n = 5 9} \\
\mathbf{x}\end{array}$ & $\begin{array}{l}\mathbf{n = 5 9} \\
\text { minimum }\end{array}$ & $\begin{array}{l}\mathbf{n = 5 9} \\
\text { maximum }\end{array}$ & $\begin{array}{l}\text { Shapiro-Wilk test } \\
\text { p score }\end{array}$ \\
\hline Before education & 79 & 40 & 100 & 0,026 \\
\hline After education & 81 & 30 & 100 & $\mathbf{0 , 0 0 0}$ \\
\hline After 3 months later & 89 & 69 & 100 & $\mathbf{0 , 0 0 2}$ \\
\hline
\end{tabular}

$p<0.05$ 


\section{Discussion}

Behaviors that can last for life are gained mostly in the school-aged child period (12). Nutrition education is important for improving the quality of life and health of future generations.

In our study, $40.7 \%$ of the students had nutrition education before the study. Sabbağ (13), with $5^{\text {th }}$ and $6^{\text {th }}$ grade students $(n=549)$, stated that only $29.1 \%$ of the students received nutrition education. The majority of the students did not receive education in nutrition, indicating that nutrition education is still inadequate in our country.

In our study, the three-meal consumption rate decreased compared to the pre-education, but the ratio of those who consumed four meals a day or more increased. The schoolaged child should be fed at least three meals or four to five meals a day. This result shows that the given education is not only in the level of knowledge but also transformed into positive behavior. The study of Kılıç and Uzunçakmak (14) on feeding behavior and nutrition education habits of students ( $n=305), 79.4 \%$ of the students eat three meals or more. In the study by Oğuz and Derin (15) on the investigation of nutrition habits, it was stated that $34.4 \%$ of the students had three meals or more. Our study results are higher when compared to the study done by Oğuz and Derin (15).

For an adequate, balanced, healthy and moral boosting nutrition, it should be consumed in the required quantities giving importance to various food types instead of eating one or two types of food (16).

In our study, consumption of vegetable and vegetable dishes increased after education but dropped three months after education. Although there was no change in the consumption of dairy products after education, there was an increase three months after education. Increasing the consumption of dairy products into behavior is a positive result in terms of bone and dental health since the schoolaged child has a high calcium requirement. The egg is a very important protein, it is positive that most of the students consume eggs every day. Seafood consumption increased after education but decreased three months after education. There is a negative difference between posteducation results and results 3 months after the education according to Wilcoxon-Mann-Whitney test (Table I). The fact that the consumption rate of seafood in Izmir, which is a coastal province, is lower than expected is thought to be because the region in which the research was conducted is influenced by migration.

No significant changes in food consumption in general after the education and 3 months after the education requires more serious consideration of nutrition education and coordination of the Ministry of National Education, the entire school team, the family, the school health nurse and other health workers.

Compared with the studies of Özilbey (17) and Derin et al. (18), the consumption of eggs each day was found to be higher. Consumption of milk and dairy products is higher than the study of Kutlu and Çivi (19).

As a result of the research named "bring a little fruit to the school" conducted in an elementary school in Italy by Panunzio et al. (7), it was determined that there is an increase in the consumption of fruit-vegetable-legume after nutrition education.

There is also a strong relationship between nutritional programs and school meals and the cognitive performance of students and educational achievement (20).

Nutrition information of $62.7 \%$ of the students was "very good" before the education, nutrition information of $71.2 \%$ after education and $91.5 \%$ three months after education was "very good". A statistically significant difference was found between pre-and post-education nutrition knowledge levels of the students. In the study of Choi et al. (21), the analysis for nutrition attitude and dietary behavior $(n=493)$ showed that nutrition attitude was slightly higher in girls with 7.59 points than in boys with 7.31 points, which showed a statistically significant difference $(p<0.05)$. In the study by Lin et al. (22), the nutrition knowledge of elementary school children was fair. On average, $1^{\text {st }}$ to $3^{\text {rd }}$ graders and $4^{\text {th }}$ to $6^{\text {th }}$ graders answered $67.3 \%$ and $71.4 \%$ of the nutrition knowledge questions correctly. In a study of 1.704 Indian American children by Davis et al. (23), nutrition education was found to increase nutrition knowledge and physical activity levels. In a study conducted by Nguyen (24) to investigate the effect of nutrition education, nutrition knowledge significantly increased from 15.58 to 19.73 , baseline, and post intervention respectively. With Kandiah and Jones (25), their study showed the effectiveness of a nutrition education program on nutrition knowledge scores and the healthy food choices of fifth grade children. In another study conducted by Drummond (26), students increased their understanding of the principles of healthy eating and developed skills to make decisions about healthy eating behaviors. Our study and other studies show that nutrition education can improve the knowledge of students significantly $(27,28)$.

\section{Conclusion}

According to these results, it can be said that the individual and therefore society should be conscious about nutrition. With nutrition education, the society should feed itself according to adequate and balanced nutrition rules ensuring that the community is healthy, and in this way the expenditures made for health should be minimized. This 
can only be achieved through education. The earlier the start of nutrition education, the more successful it will be. The family is also very important in giving children a positive nutritional habit during the school years. For this reason, it is suggested that family education should be included in the pattern of studying similar studies.

Within the scope of community health protection, school administrations can work in cooperation with the relevant government institutions. Country policies can be established and applied in the fields of health, nutrition, and physical activity.

\section{Ethics}

Ethics Committee Approval: Required permissions were obtained from the Scientific Ethics Committee of Ege University Nursing Faculty, the Ministry of Education and the Primary School attached to the Ministry of National Education (approval number: 27344949-1267).

Informed Consent: Verbal and written approvals were obtained prior to the children's education, by explaining the purpose of the study, benefits to be obtained from the study and time to be spent for the education.

Peer-review: External and internal peer-reviewed.

\section{Authorship Contributions}

Concept: Z.D.B., H.U., Design: Z.D.B., H.U., Data Collection or Processing: H.U., Analysis or Interpretation: H.U., Literature Search: H.U., Writing: H.U.

Conflict of Interest: No conflict of interest was declared by the authors.

Financial Disclosure: The authors declared that this study received no financial support.

\section{References}

1. Food and nutrition policy for schools: A tool for the development of school nutrition programmes in the European Region. Programme for Nutrition and Food Security. WHO Regional Office for Europe, Copenhagen: 2006.

2. Aldinger $\mathrm{CE}$, Jones JT. WHO information series on school health document for healthy nutrition: an essential element of a health-promotingschool. Geneva: 1998. http://www.who.int/ school-youth-health/media/en/428.pdf?ua=1

3. Aral N. Çocuk gelişiminde oyunun önemi: çağdaş eğitim. Ankara: Tek Işık Yayıncılık; 2000:3-27.

4. Poyraz H. Okul öncesi dönemde oyun ve oyuncak. 2. Baskı. Ankara: Arı Yayıncılık; 2003:4-47.

5. Poyraz H, Dere H. Okul öncesi eğitimin ilke ve yöntemleri. 15. Baskı. Ankara: Arı Yayıncılık; 2002:8-56.

6. Hoffman IB, Kelleher C, Pover TS, Leff S. Promoting healty food consuption among young children; evaluation of multi-component nutrition education program. I Sch Psychol 2004;42:45-60.

7. Panunzio M, Antoniciello A, Pisano A, Dalta S. Nutrition education intervention by teachers may promote fruit and vegetable consumption italian students. Nutrition Research 2007;27:524-8.
8. Prelip M, Kinsler J, Thai JL, Erausquin JT, Slusser W. Evaluation of a school-based multicompnent nutrition education program to improve young children's fruit and vegetable consuption. / Nutr Educ Behav 2012;44:310-8.

9. Törüner $K E$, Büyükgönenç L. Çocuk sağlığı temel hemşirelik yaklaşımları: çocuklarda beslenme ve beslenme sorunları. Ankara: Gökçe Ofset 2013;209-35.

10. Koçyiğit S, Tuğluk MN, Kök M. Çocuğun gelişim sürecinde eğitsel bir etkinlik olarak oyun. Atatürk Üniversitesi Kazım Karabekir Eğitim Fakültesi Dergisi 2007;16:325-42.

11. Pehlivan H. Oyun ve öğrenme. 3. Baskı. Ankara: Arı yayıncılık; 2012.

12. Ersoy G. Okul çağı ve spor yapan çocukların beslenmesi. 1. Baskı. Ankara: Ata Ofset; 2001.

13. Sabbağ Ç. Illköğretim 5. ve 6. Sınıf öğrencilerine verilen beslenme eğitiminin, beslenme bilgi, tutum ve davranışlarına etkisinin değerlendirilmesi. Gıda Teknolojileri Elektronik Dergisi 2011;6:1-13.

14. Kılıç M, Uzunçakmak T. Feeding Behavior and Nutrition Education in Primary School Students: A School-Based Study. I Clin Anal Med 2015;6:315-9.

15. Oğuz \$̧, Derin DÖ. An investigation of some nutrition habits of 60-72 month-old children. Elementary Education Online 2013;12:498-511.

16. Baysal A, Beslenme. 12.Baskı. Ankara: Hatiboğlu Yayınları;2012.

17. ÖzilbeyP.illköğretim1.kademeöğrencilerdeobeziteprevelansının belirlenmesi ve beslenme alışkanlıklarının incelenmesi, Turk J Public Health 2015;13:30-9.

18. Derin ÖD, Akaroğlu G, Şahin S et al. International Peer-Reviewed Journal of Nutrition Research 2016;7:1-22.

19. Kutlu R, Çivi S. Özel Bir Illköğretim Okulu Öğrencilerinde Beslenme Alışkanlıklarının Ve Beden Kitle Endekslerinin Değerlendirilmesi. Fırat Tıp Dergisi 2009;14:18-24.

20. Mandos Y, Kafatos I, Kafatos A. Ten year follow-up of the creten health and nutrition education program on children' sphysical activity levels. Preventive Medicine 2006;43:442-6.

21. Choi ES, Shin NR, Jung El, Park HR, Lee HM, Song KH. A study on nutrition knowledge and dietary behavior of elementary school children in Seoul. Nutr Res Pract 2008;2:308-16.

22. Lin W, Yang HC, Hang CM, Pan WH. Nutrition knowledge, attitude, and behavior of Taiwanese elementary school children. Asia Pac J Clin Nutr 2007;16:534-46.

23. Davis SM, Clay T, Smyth M, et al. Path ways curriculum and family interventions to promote healthful eating and physical activity in American Indian school children. Prev Med 2003;37:24-34.

24. Nguyen B. Impact of a nutrition education intervention on nutrition knowledge and dietary intake of fruits, vegetables, and milk among fourth and fifth-grade elementary school children. I Nutr Educ Behav 2016;48:80.

25. Kandiah J, Jones C. Nutrition knowledge and Food Choices of Elementary School Children. Early Child Development and Care 2002;172:269-73.

26. Drummond CE. Using nutrition education and cooking classes in primary schools to encourage healthy eating. Journal of Student Wellbeing 2010;4:43-54.

27. Kostanjevec S, Jerman J, Koch V. The effects of nutrition education on $6^{\text {th }}$ graders knowledge of nutrition in nine-year primary schools in slovenia. EURASIA / 2011;7:243-52.

28. de Villiers A1, Steyn NP, Draper CE, et al. Primary school children's nutrition knowledge, self-efficacy, and behavior, after a three-year healthy lifestyle intervention (healthkick). Ethn Dis 2016;26:171-80. 